\title{
DETERMINISM IN LAW: APPLIED AND THEORETICAL ASPECTS ON THE EXAMPLE OF CRIMINAL LAW
}

\section{ДЕТЕРМІНІЗМ У ПРАВІ: ПРИКЛАДНІ ТА ТЕОРЕТИЧНІ АСПЕКТИ НА ПРИКЛАДІ КРИМІНАЛЬНОГО ПРАВА}

\author{
Koval M.M., Ph.D. in Law, \\ Associate Professor of the Department of Criminal Law and Procedure \\ Institute of Jurisprudence and Psychology \\ of the Lviv Polytechnic National University
}

Any socio-economic system has a tendency to develop. However, development itself as a process occurs under the influence of a large number of factors that can both stimulate and inhibit it, impeding the activation of transformation processes and the emergence of progressively oriented changes. At the present stage, the most important thing is to identify the determinants of development that will accelerate its pace and ensure the progressive nature of change.

At the same time, the identification of development determinants should be based on the use of a clearly defined conceptual and categorical apparatus, which involves, first of all, the definition of the essence of the concept of "determinants" and the classification of features by which the determinants of development can be classified.

It should be pointed out the considerable scientific achievements of the authors regarding the nature of the determinants of development and their classification, but at the same time there is a high degree of uncertainty and fragmentation of research in this area, the essence of the determinants needs clarification, and their specific manifestations of systematization.

An attempt to identify the most appropriate, given the mutual logical approaches to establish causation as not only within the objective side of the crime: communication actions (inaction) and the results that come, also consider the role of the subjective side of crime which is based on determinism. Analyzed is based on the difference of the causes and conditions that produce a result. Also a number of specific features of causation is considered. It is determined the causal link - a sign of the objective of not all, but only so-called "material" of the crimes. When a crime has "material" composition, it is always necessary to establish a causal relationship between the criminal action and the consequences that came.

A person may, by law, responsible only for the consequences which were the cause due to her behavior. If a causal relationship between action and outcome is absent, these effects cannot be sane person and cannot be responsible for them.

Key words: determinism, causality, conditions, causation

Будь-яка соціально-економічна система має схильність до розвитку. Однак безпосередньо розвиток як процес відбувається під впливом значного числа чинників, які можуть як стимулювати, так і стримувати його, перешкоджаючи активізації трансформаційних процесів та виникненню прогресивно орієнтованих змін. На сучасному етапі постає вкрай важливе завдання щодо виявлення детермінантів розвитку, що сприятимуть прискоренню його темпів та забезпечать прогресивний характер змін. Водночас виявлення детермінантів розвитку має ґрунтуватися на використанні чітко окресленого понятійно-категоріального апарату, що передбачає перш за все визначення сутності поняття «детермінант» та систематизації класифікаційних ознак, за якими детермінанти розвитку можуть бути класифіковані.

Слід відзначити вагомий науковий доробок перерахованих авторів щодо сутності детермінантів розвитку та їх класифікації, але поряд із цим є високий ступінь невизначеності і фрагментарності досліджень у цьому напрямі, сутність детермінантів потребує уточнення, а їх видові прояви систематизації.

Спроба визначити найбільшу доцільність, з огляду на взаємні логічні підходи, причинність не тільки в межах об'єктивної сторони злочину, а також враховувути роль суб'єктивної сторони злочину, заснованої на детермінізмі. Проаналізовано причини та умови скоєння злочину. Також розглядається низка специфічних особливостей причинно-наслідкового зв'язку. Визначено, що причинно-наслідковий зв'язок - ознака об'єктивності не всіх, а лише так званих «матеріальних» злочинів. Коли злочин має «матеріальний» склад слід встановити причинно-наслідковий зв'язок між кримінальною дією та наслідками, що настали.

За законом особа може відповідати лише за наслідки, які були причиною внаслідок її поведінки. Якщо причинний зв'язок між дією та наслідком відсутній, особа за наслідки не може нести відповідальність.

Ключові слова: детермінізм, причинність, умови, причинний зв'язок.

Formulation of the problem. In today's conditions, when Ukraine takes a firm course on building a democratic rule of law, the protection of the rights and legitimate interests of the person, including the fight against crime, becomes especially relevant. One of the fundamental issues in criminal law is the problem of causality.

Analysis of recent research and publications. Among legal scholars, a significant contribution to the development of the problem of the relation between causality and determinism was made by S.R. Bagirov, S.O. Efremov, M.I. Kovalev, O.M. Koshtenko, V.M. Kudryavtsev, V.G. Makhashvili, V.B. Malinin, P.S. Matyshevski, B.A.Myslivyi,A.A.Muzyka,V.A.Nersesian,A.A.Piontkovsky, V.S. Prokhorov, M.S. Tagantsev, A.A. Ter-Akopov, G.V. Timeyko, A.N. Traynin, M.P. Yablokov, N.M. Yarmysh.

The purpose of the article is to investigate the legal issues of determinism in law on the example of criminal law.

Presenting main material. In its historical development, determinism has undergone two main stages the phase of classical (metaphysical, mechanistic) determinism and the stage of determinism postclassical, dialectical in nature.
In the sources of the metaphysical interpretation of determinism, we discover the atomistic concept of Democritus, which (unlike the Epicurus concept) denied chance by accepting it simply as an unknowable necessity. Such determinism is further developed by F. Bacon, T. Hobbes, B. Spinoza, R. Descartes, J. Lametry, P. Holbach, and other modern-day philosophers. Drawing on the work of his predecessors and on the basic ideas of natural science I. Newton and K. Linnaeus, the French astronomer and mathematician P. Laplace in the work "The Experience of the Philosophy of Probability Theory" (1814) brought the ideas of mechanistic determinism to a logical end: he proceeds from the postulate, accordingly to which of the knowledge of the original causes one can always unambiguously deduce the consequence.

Determinism is a materialistic doctrine of the universal causal conditionality of the phenomena of nature, society and thinking. First we need to find out what causality means. Causality is the necessary connection between the phenomena of the material world, of which some (causes) cause others (consequences) [1].

The causal connection between the phenomena of nature and society, existing outside the consciousness of man, in 
the things and processes that take place in objective reality, contains certain conditions. Under the conditions are sometimes understood not the main, but secondary causes of the phenomenon, which can not give rise to phenomena as a whole, but determine certain parties, features, individual features of a single phenomenon in the mass of well-defined, homogeneous and significant features of the phenomenon [2].

It is worth agreeing with the German philosopher G. Kreber, who believes that there are two aspects at the heart of the difference between causes and conditions: genetic and dialectical. Genetic: the cause generates an investigation, and the condition only contributes to it, allowing the cause to work. Dialectical aspect is the opposite reason to the conditions in its variability, i.e. fatigue. This criterion can only be used when the cause is active. When faced with cases of passive phenomena, the distinction between specific cause and condition disappears. In this case, we can only talk about the main reason. Going for a clearer delineation of causes and conditions, A.P. Sheptulin emphasizes that the set of factors necessary for the occurrence of a phenomenon should not dissolve the cause, and the main thing that distinguishes it from the conditions and is the most important part of the category of the cause is the moment of activity, that the cause is the driving force, causes corresponding changes in things, phenomena [3]

Separation of causes and conditions is of considerable scientific and practical value. All authors investigating the problem of causation in criminal law, note the relative nature of the differences between causes and conditions: the full cause includes the conditions, and therefore conditions in the broad sense also serve as causes. Without conditions, the reasons could not have arisen or would have been different. Conditions are secondary causes of criminal consequences. Qualitative differences between the individual circumstances that, in the aggregate, have resulted in a criminal outcome, are important both for the resolution of the question of the limits of criminal responsibility and especially for determining the degree of punishment of perpetrators. In fact, if conditions are broadly considered to be the causes of an event, then there is no doubt that these "causes" cannot play the role of the determining main factors in force. Thus, differences between conditions, on the one hand, and not the main, minor causes, on the other, are sometimes erased.

The doctrine of causal connection based on dialectical materialism is based on the science of criminal law of Ukraine. This science does not create any particular, "legal", "its", "independent" concept of causal connection, other than the understanding of causality in dialectical materialism, it only specifies it in relation to those events and phenomena that study criminal law.

There is no doubt that man and his understanding are fully subject to the general law of causality. Of course, on this basis it is impossible to conclude that in the problem of causality in law there are no peculiarities, no specifics in comparison with the problem of causality in other branches of science, and it is impossible to put a sign of equality between the causal conditionality of human behavior, on the one hand, and causal observations in the field of physical or biological processes on the other. Unlike the latter, the law deals with relations between people. When we investigate causation in law, the object of the study is such changes in the world around us, when one of the causes of such changes (events) was human behavior, and one of their consequences was a socially dangerous result. When talking about a causal link in law, they necessarily mean such a segment of the causal chain, in which one link is the behavior of a person who has its own characteristics.

In criminal law, causality must be investigated not only within the objective side of the crime: the link between the action (inaction) and the resultant event; also consider the role of the subjective side of the crime. After all, the will of a person is able to act and act as a cause of criminal behavior and because of this it cannot and should not be excluded from the sphere of investigation of crime from the angle of causality.

Causation is a necessary sign of crimes with material composition. Therefore, a clear definition of this concept is of great practical importance. Particularly difficult is establishing a causal link in the investigation of motor vehicle crimes, violations of the requirements of the legislation on labor protection, violation of the rules of storage, use, exchange, transportation of radioactive materials, etc. The correctness of the matter depends on the verdict's validity [4]

Thus, the verdict of the district court of L. was convicted under Article 286 of the Criminal Code of Ukraine. As the court admitted, L., driving on a KamAZ car at $10 \mathrm{pm}$ with the passing beam of headlights at a speed of $55 \mathrm{~km} / \mathrm{h}$, saw a car VAZ, that began to leave on the route at a distance of $60 \mathrm{~m}$. L., alleged violations of the rules of the road, did not slow down and, hoping that the driver of the VAZ would stop, used in order to avoid collision unjustified maneuver, having left on the lane of oncoming traffic. However, he did not stop and also left on the left side of the road, where there was a collision of vehicles. As a result, a VAZ driver and two of his passengers were fatally injured. But the court did not take into consideration that the accident on the road was created, first of all, by a VAZ driver who, on a traffic violation, left the road without lights, which prevented L. from being able to properly navigate in a sudden situation. Therefore, L.'s actions were not in the necessary causal connection with the effects of the collision of the vehicles. In such circumstances, the judicial panel of the Supreme Court of Ukraine overturned the verdict against $\mathrm{L}$. in the absence of a crime in his actions.

The question is: what action should be considered as the cause of the crime? In fact, you can agree with the opinion of prof. YN Traynin: "The mechanism of human activity and its deepest connection with social relations and numerous phenomena of nature is even more complex and deeper. And it can be said that all criminalists in the world would not be able to trace from beginning to end all causal connection phenomena and actions that led to the criminal result" [5].

Considering the concept of reason, they give it the property of active principle, that is, understand the cause of a phenomenon that can cause such changes in the outside world. In everyday life, the connection between the actions of a person and the resultant outcome is so obvious that, even in a judicial investigation of a case, this issue does not cause any difficulties. However, in some cases, causation becomes a stumbling block in the resolution of specific cases. An incorrectly interpreted relationship between events gives rise to miscarriages of justice.

One of the indispensable features of the objective side of traffic crimes is the causal link between the violation of traffic safety rules and the operation of transport and damage caused in the form of accidents with people, accidents or other grave consequences. Incorrect causation is the most common mistake in investigating and investigating criminal cases in this category.

Practice shows that causality in the affairs of this category has a number of specific features. First, it draws attention to the multiplicity of factors (mostly objectively unfavorable ones) that affect the behavior of the subject of a traffic crime and significantly complicate the development of a chain of causality. It is precisely because of the large variety of factors that causality in transport cases is very rarely direct and unambiguous. These factors are most often the various production processes, forces of nature, hidden vehicle defects, misconduct of other road users, and so on. The correlation of causal factors and their degree influences the criminal outcome, which in different situations may not be the same. However, there must be a manifestation of these factors in violation of traffic safety and transport operating rules.

The science of criminal law, as we have noted, does not and does not form its own specific legal concept of causal 
connection. Criminal law only specifies his philosophical notion of those events and phenomena that have criminal significance.

Since causation is an objective category, this problem must be resolved not subjectively, but on the basis of the study and consideration of all objective laws. Such a methodological approach is inherent in the theory of necessary causation. The quintessence of this theory is that it attaches importance to the sign of the objective side of the crime, not to any causal connection between the phenomena, but only to the one when the consequence becomes necessary, objectively natural, and not a random result of action [4].

To properly determine whether or not a causal connection the rules must be followed:

1. Cause in time always precedes consequences. The phenomenon that has occurred after the consequences cannot be the cause.

Socially dangerous action precedes criminal consequences in time, and action is the necessary condition that prepared and determined the possibility of consequences. The absence of such a sequence indicates that the act cannot be the cause of the consequences.

At the same time, it should be borne in mind that after that it does not yet indicate that it is the cause of it, since certain consequences can be borne by different causes.

The external sequence of events alone cannot be the basis for establishing a causal link.

2. In order to recognize an act as a cause of criminal consequences, it must be stated that it was not only preceded by the consequences, but that those consequences were caused by the act itself and not by another.

The reason is only the act that created the opportunity, the conditions of the consequences, which led to their occurrence and made them valid, ensured their implementation, realization.

3. The causal link between specific actions and their consequences is where those actions were a necessary condition for their occurrence - a condition without which there can be no such consequences. If action was not a necessary condition for the occurrence of certain consequences, there is no causal link between them.

Therefore, not every condition that contributed to the occurrence of the consequences can cause these effects.

Acts or omissions can only cause criminal consequences if they were a necessary condition for those consequences, without which these consequences would not have occurred.

4. An act or omission may be the cause only if the consequences occurring are necessary and not accidental.

The relationship between action and consequence, while always objective, may be necessary or accidental for a particular action.

Communication has the necessary character when its consequences are born by the internal development of action, its peculiarities, when they are inherent to it.

In criminal law, the term "case" (or case) is used as innocently causing the result in the absence of intent and negligence on the part of the person. Case indicates a certain mental state of the subject. It acts as a subjective category. However, in criminal law, the case acts as an objective category and is considered irrespective of the issue of the subject's guilt [6].

Proponents of the theory of "necessary causing" do not take into account all the features of these categories and identify the need for the case in the investigation of crime with the study of causation as one of the elements of the objective side of the crime, which is not unambiguous. Based on this theory, it is impossible to justify criminal liability for negligent crimes, and especially for crimes committed through negligence. Here, a socially dangerous result occurs as a result of intertwining random events, and in such cases, according to theory, criminal liability should be excluded.

Professor A.N. Trainin's theory suggests that all actions that gave rise to this criminal result must be distinguished by the degree of the cause. The scientist assumes that any element of the crime may have different degrees. Yes, the wine may be deliberate or negligent, the intention itself may be preconceived or suddenly arising, or the crime may be greater or less severe. In this case, "reducing one of the elements of the composition to a negligible level can deprive each composition of criminal value" [6]. In this respect, it is indistinguishable from other features of the composition and causing of a socially dangerous consequence: the resultant action is not homogeneous.

This provision is shown by the example of complicity:Article 19 of the Criminal Code of Ukraine provides in determining the responsibility of accomplices to take into account the degree of their involvement in the crime, i.e. the author equates the degree of involvement and the degree of involvement. This is the criterion for determining the individual responsibility of the accomplice. For example, in theft: one is the perpetrator, the other is the instigator, the third is a helper, all causally related to the criminal result, but the degree of this connection is not the same. And the most causal link can be expressed to a greater or lesser degree.

A causal link is possible not only between actions and consequences. Socially dangerous consequences can also be caused by inaction, but such a connection has certain peculiarities. They are caused by the specifics of the inaction itself. Inactivity can be manifested in non-interference, noninterference with another person's dangerous actions or the harmful effects of the forces of nature.

Inaction may also be the failure to act on certain benefits in the public interest. In the first case, the consequence is the deterioration of the state of those social relations that constitute the content of the immediate object of the crime. The peculiarity of the consequence in the second case is that public relations do not change for the worse, but their condition should be improved. For example, if negligence can cause inactivity to supply raw materials to the manufacturing company, as a result, the enterprise (the recipient of the raw material) will not be able to produce the products, eventually causing harm to society.

Conclusion. Therefore, causation is a sign of the objective side of not all, but only the so-called "material" crimes. In a crime that has "material" structure, it is always necessary to establish a causal link between the action and the criminal consequences that come.

According to the law, a person can only be held responsible for the consequences which were causally caused by his behavior. If, however, there is no causal link between the action and the consequences, these consequences cannot be blamed and the person cannot be held responsible.

In the criminal law of Ukraine, there is a single doctrine of causality, based on the philosophy of determinism.

\section{REFERENCES}

1. Великий тлумачний словник сучасної української мови (з. Дод. на СD): 250000 / уклад. і голов. ред. В.Т. Бусел. Київ ; Ірпінь : Перун, 2007. 1736 с.

2. Категории материалистической диалектики / Под ред. МЛ. Розенталя и Г.А. Шытракса. Москва : Политиздат, 1956. С. 95.

3. Шептулин А.П. Система категорий диалектики. Москва : Наука, 1967. 375 с.

4. Ярмиш Н.М. Теоретичні проблеми причинно-наслідкового зв'язку в кримінальному праві (філософрсько-правовий аналіз). Харків : Право, 2003. 512 с

5. Черненко А.К., Ременсон А.Л. Категория причинности и ее применение в уголовно-правовых и криминологических исследованиях. Проблемы причинности в криминологии и уголовном праве. Владивосток : Из-во Дальневосточного университета, 1983. С. 10-22.

6. Трайнин А.Н. Общее учение о составе преступления. Москва : Госюриздат, 1957. 364 с. 